\title{
PERKEMBANGAN TEKNOLOGI DAN PERILAKU MENYIMPANG DALAM MASYARAKAT MODERN
}

\author{
Muzaini \\ SMP Negeri 1 Gemolong Sragen
}

\begin{abstract}
Abstrak
Perkembangan teknologi yang pesat dewasa ini telah menjadikan negara-negara yang sedang berkembang mengalami perubahan-perubahan dalam aspek sosial dan ekonomi. Proses modernisasi di bidang ekonomi dan sosial mengakibatkan perubahan bentuk masyarakat dari bentuk tradisional menuju ke bentuk modern. Di satu sisi perkembangan teknologi dalam masyarakat modern memberikan kemudahan-kemudahan bagi kita dalam berbagai hal, seperti dalam transportasi dan berkomunikasi. Akan tetapi, perubahan-perubahan teknologi dan modernisasi ternyata dalam sisi lain berdampak negatif. Masyarakat yang sedang berubah merasakan seperti dalam keterasingan di dalam menghadapi perubahan yang terjadi. Dampak dari berbagai perubahan dirasa tidak semua menguntungkan.bagi masyarakat Hal ini dapat dilihat dari berbagai perilaku menyimpang yang muncul dalam masyarakat modern. Munculnya banyak perilaku menyimpang dalam masyarakat modern perlu diwaspadai agar tidak mengancam kehidupan masyarakat modern, sehingga terbentuk masyarakat kekotaan yang teratur, tertib dan nyaman, serta memberikan harapan kehidupan masa depan yang lebih baik.
\end{abstract}

Kata kunci: perkembangan teknologi, masyarakat modern, dan perilaku menyimpang

\section{TECHNOLOGICAL ADVANCES AND DEVIANT BEHAVIOR IN MODERN SOCIETY}

\author{
Muzaini \\ SMP Negeri 1 Gemolong Sragen
}

\begin{abstract}
The rapid advances in technology nowadays have made developing countries experiences changes in the social and economic aspects. Economic and social modernization process results in changes form a traditional society to a modern one. On the one hand, advances in technology in the modern society provide easy accesses, such as in transportation and communication. However, these advances also bring negative impact. The changing society sometimes feel alienated in facing the changes. This may lead to the occurence of deviant behaviours in the modern society. This phenomenon has to be anticipated for it threatens the modern life from being organized, orderly, comfortable, and providing a better life in the future.
\end{abstract}

Keywords: The development of technology, modern society, and deviant behavior 


\section{PENDAHULUAN}

Dalam kehidupan sehari-hari kita tidak dapat melepaskan diri dari perubahan-perubahan yang terjadi pada masyarakat di sekitar kita atau pada diri kita sendiri. Seperti ungkapan dari Everlyn Waugh yang dikutip oleh Renald Kasali, dikatakan bahwa Perubahan adalah pertanda kehidupan. Manusia yang hidup selalu berubah. Bermula ia lahir dari seorang bayi yang hidupnya tergantung pada orang lain, kemudian ia belajar berjalan, lalu ia berlari dengan kedua tangan dan kakinya. Setelah ia menjadi mahluk dewasa menghadapi berbagai macam persoalan (Kasali, 2005, p.5).

Masyarakat senantiasa mengalami perubahan, baik perubahan yang cepat maupun perubahan yang lambat. Perubahan masyarakat bisa terjadi dari bentuk kehidupan masyarakat yang sederhana hingga bentuk masyarakat yang kompleks. Seperti pada ungkapan bahwa di dunia ini tidak ada yang abadi, kecuali perubahan itu sendiri yang abadi. Seorang futuris Amerika ternama, Alvin Toffler seperti yang dikutip Dadang Supardan dalam bukunya yang berjudul Pengantar Ilmu Sosial, mengatakan bahwa perubahan tidak hanya penting bagi kehidupan tetapi perubahan itu sendiri adalah kehidupan. Masyarakat pun terus berproses dalam tujuan yang tidak kita diketahui (Supardan, 2011, p.142).

Proses perubahan kehidupan manusia dapat diketahui dari sejak awal dunia dihuni manusia hingga dewasa ini. Alvin Toffler seperti yang dikutip Dwiningrum, menganalisis gejala-gejala perubahan dan pembaruan peradaban manusis akibat kemajuan ilmu teknologi ke dalam tiga gelombang peradaban manusia saat ini (Dwiningrum, 2012, p.45) sebagai berikut.

a. Gelombang I. peradaban teknologi pertanian berlangsung mulai 8000 SM 1500M;

b. Gelombang II, peradaban teknologi industri berlangsung mulai $1500 \mathrm{M}$ 1970M;

c. Gelombang III, peradaban informasi berlangsung mulai $1970 \mathrm{M}$ - sekarang.

Setiap gelombang memiliki karakteristik khusus yang membedakan antara satu jaman dengan jaman yang lain. Gelombang perubahan pertama terjadi berkaitan dengan revolusi hijau (era pertanian). Karakteristik era pertanian antara lain pertanian terbatas pada pengolahan lahan pertanian untuk mencukupi kebutuhan makan sendiri, sebagai peralihan dari masa food gathering (meramu dan mengumpulkan makanan), dengan kehidupan yang berpindah-pindah menjadi food producing (bercocok tanam), dengan kehidupan yang menetap. Jaman ini berlangsung kirakira mulai $8000 \mathrm{SM}-1500 \mathrm{M}$;

Gelombang perubahan kedua merujuk pada revolusi industri (era perindustrian). Era industri dimulai sejak terjadinya revolusi industri di Inggris, kemudian diikuti oleh negara-negara di Eropa lainnya. Masa diawali dengan penemuan mesin uap, kemudian ditemukan mesin elektromagnetik, dan sebagainya. Mesin-mesin tersebut menggantikan tenaga manusia dalam memproduksi barang, dan sebagai alat transportasi. Karakteristik era industri ditandai dengan bentuk keluarga menjadi lebih kecil, beralih pekerjaan dari lahanlahan pertanian ke pabrik-pabrik, era ini dimulai kira-kira tahun 1500 hingga 1970-an.

Gelombang perubahan ketiga disebut era informasi, yang serupa dengan jaman pasca industri, suatu periode yang diawali pada pertengahan/akhir 1965-an hingga sekarang ini. Era informasi dialami oleh negaranegara yang menguasai teknologi tinggi seperti Amerika Serikat, negara-negara Eropa Barat, dan Jepang. Jaman ini ditandai dengan peran sistem elektronika yang membantu mempercepat komunikasi, perhitungan, dan penyebaran informasi. Era informasi didukung oleh ketersediaan teknologi secara luas seperti komputer, telekomunikasi, robot, dan bioteknik, telah meninggalkan tanda-tanda pada karakteristik sosial masyarakat. Perubahan mendasar dalam perilaku sosial sekarang dapat dilihat seperti pada organisasi angkatan kerja, pendidikan pemuda serta keberagaman dalam bentuk keluarga.

Dalam membicarakan perkembangan teknologi, pada dasarnya kita tidak bisa melepaskan dari perkembangan masyarakat itu sendiri. Teknologi merupakan salah satu bagian penting dalam kehidupan masyarakat, baik masyarakat modern maupun masyarakat yang sedang berkembang. Sejalan dengan perkembangan kehidupan masyarakat, perkembangan teknologi semakin berjalan cepat dan pesat sesuai dengan tuntutan kebutuhan masyarakat modern. 
Pada masyarakat di negara-negara yang sedang berkembang dikenal dengan Dunia Ketiga, seperti negara Indonesia, perkembangan teknologi baru mengalami perkembangan yang pesat sebagai konsekuensi mengejar ketinggalan terhadap negara-negara maju, seperti negara-negara di Eropa dan Amerika. Upaya untuk mengejar ketinggalan-ketinggalan dilakukan melalui upaya modernisasi.

Berbagai definisi mengenai modernisasi diberikan oleh para sosiolog dalam kerangka perspektif evolusioner yang mencakup transisi multilinier masyarakat yang sedang berkembang dari tradisi ke modernitas. Misalnya Everett Rogers sebagaimana dikutip oleh Abraham, mendefinisikan bahwa modernisasi merupakan proses individu berubah dari cara hidup tradisional menuju gaya hidup lebih kompleks dan maju secara teknologis serta cepat berubah (Abraham, 1991, pp.4-5). Rodney Stark memberikan definisi modernisasi sebagai berikut: Modernization is the process by which agrarian societies were transformed into industrial societies. Artinya Modernisasi adalah proses dimana masyarakat agraris yang berubah menjadi masyarakat industri (Stark, 1992, p.495).

Dalam konteks sosial, modernisasi di dalam masyarakat sedang berkembang berbeda dengan modernisasi di negara-negara Barat. Modernisasi di Barat merupakan proses bertahap evolusi dari pertanian menjadi masyarakat yang sepenuhnya industri dan perkotaan, sedangkan modernisasi di negaranegara Berkembang dipaksakan melompat dari budaya bajak yang sederhana menjadi era jet modern di dalam satu dekade. Bagi bangsa-bangsa berkembang modernisasi tampil sebagai suatu budaya yang penuh dengan pertentangan yang telah disesuaikan, diserap dan dipelihara sesuai dengan kecepatan mereka sendiri (Abraham, 1991, p.14).

Kehidupan modern atau modernitas yang berawal di Eropa pada abad ke-17. Menurut Gidden yang dikutip oleh Ritzer, bahwa modernisasi dilukiskan sebagai "Juggernaut" (panser raksasa), khususnya untuk melukiskan tahap kemajuan modernitas-modernitas radikal, tinggi atau akhir. Modernitas dalam bentuk panser raksasa ini sangat dinamis. Kehidupan modern adalah sebuah "dunia yang tak terkendali". Bayangan tentang panser raksasa adalah bayangan tentang sesuatu yang bergerak melalui rentang waktu dan ruang fi- sik. Citra panser raksasa ini untuk menerangkan bahwa mekanisme modern ini jauh lebih besar kekuasaannya ketimbang agen yang mengemudikannya (Ritzer, 2005, pp.552-553).

Dalam kehidupan masyarakat modern, kita dapat melihat pola hidup dan perilaku sebagian masyarakat yang tampak berbeda dengan pola hidup dan perilaku yang biasa dilakukan oleh sebagian besar anggota masyarakat tradisional pada umumnya. Kejanggalan-kejanggalan semacam itu menimbulkan suatu anggapan telah terjadi berbagai penyimpangan sosial, karena munculnya perilakuperilaku yang berbeda dari sebagian warga masyarakat tersebut. Sebenarnya sulit untuk menentukan apakah perilaku seseorang itu dikatakan menyimpang atau tidak. Hal ini perlu adanya kajian yang lebih mendalam, sehingga ditemukan jawaban yang dapat memberikan penjelasan tentang gejala-gejala yang muncul dalam masyarakat tersebut.

Dalam tulisan ini, penulis membahas masalah yang penting ke dalam beberapa bahasan sebagai berikut: (1) perkembangan teknologi dan modernisasi; (2) terbentuknya masyarakat modern; (3) dampak perkembangan teknologi dan modernisasi; (4) perilaku menyimpang pada masyarakat modern.

\section{PEMBAHASAN}

\section{Perkembangan Teknologi dan Modernisasi}

Perkembangan teknologi terutama yang terjadi pada era informasi mulai akhir abad ke-20 dan awal abad ke-21, berlangsung sangat cepat. Menurut Naisbitt bahwa revolusi dalam telekomunikasi menjadi faktor utama sebagai penggeraknya. Telekomunikasi sebagai kekuatan penggerak yang secara serentak menciptakan ekonomi global yang besar sekali dan menjadikan bagian-bagiannya lebih kecil dan lebih kuat. Seperti yang diprediksi oleh John Naisbitt, bahwa perkembangan teknologi informasi di dalam jaringan ekonomi global abad ke-21, akan mendorong perubahan sama pastinya seperti manufaktur mendorong perubahan di dalam era industri (Naisbitt, 1994, p.54).

Beberapa teknologi informasi yang penting selama abad ke-21 antara lain sebagai berikut.

a. Pembauran teknologi komputer, telepon, televisi bergabung menjadi satu industri telekomunikasi; 
b. Aliansi strategi menciptakan industri telekomunikasi;

c. Menciptakan jaringan dari jaringanjaringan tanpa batas, global, dan digital;

d. Komputer pribadi untuk semua orang, evolusi dalam teknologi komunikasi menciptakan revolusi dalam pembagian informasi.

Multimedia sebagai high tech/high touch pada abad ke-21, memberikan informasi digital yang akan mengubah hibrida baru produk konsumen elektronika televisi, telepon, dan komputer menjadi media interaktif. Naisbitt menyimpulkan bahwa teknologi berkembang dengan kecepatan yang semakin meningkat, dengan tiap teknologi baru menambah kecepatan dan kesanggupan teknologi yang sebelumnya (Naisbitt, 1994, pp.51-99).

\section{Terbentuknya Masyarakat Modern}

Perkembangan teknologi terkait dengan proses modernisasi yang sedang berjalan di berbagai belahan dunia, baik di negara-negara maju maupun di negara-negara yang sedang berkembang, termasuk Indonesia. Pada umumnya proses modernisasi dapat dilihat dari dua tipe, yaitu modernisasi ekonomi dan sosial.

Modernisasi ekonomi merupakan perkembangan atau "kemajuan" ekonomi yang ditandai dengan tingginya tingkat konsumsi dan standar hidup, revolusi teknologi, intensitas modal yang makin besar dan organisasi birokrasi yang rasional. Modernisasi ekonomi mencakup pembentukan sistem pertukaran moneter, peningkatan tingkat skill yang dibutuhkan melalui teknokrasi, mekanis- asi, otomatisasi dan akibat perpindahan tenaga kerja, penghitungan biaya secara rasional, spesialisasi okupasi yang makin besar dan spesialisasi fungsional, pola-pola tabungan dan investasi, alat-alat transportasi dan komunikasi yang makin cepat makin turut memudahkan dalam pemasaran, mobilitas tenaga kerja, distribusi barang-barang, dan perubahan pola konsumsi. Modernisasi ekonomi pasti diikuti dengan perluasan pengetahuan ilmiah dan inovasi teknologi, pembentukan modal, tingkat pendidikan yang cocok, spesialisasi ekonomi dan kecukupan bahan-bahan mentah, barang produksi dan konsumsi (Abraham, 1991, pp.5-6).

Adapun modernisasi sosial mencakup modernisasi politik dan psikologis. Modernisasi sosial meliputi perubahan dalam atributatribut sistemik, pola-pola kelembagaan dan peranan-peranan status dalam struktur masyarakat sedang berkembang. Unsur-unsur pokok modernisasi sosial mencakup perubahan sosial terencana, sekularisme, perubahan sikap dan tingkah laku, pengeluaran pendidikan umum yang berat, revolusi pengetahuan melalui perluasan sarana komunikasi, instrumen hubungan-hubungan sosial, dan keharusan kontraktual, diferensiasi struktural dan spesialisasi fungsional.

Masyarakat modern memiliki karakteristik yang berbeda dengan masyarakat tradisional. Di antara bentuk masyarakat tradisional dan modern terdapat masyarakat transisi. Abraham membuat rincian perbedaan antar masyarakat tradisional, masyarakat transisi dan masyarakat modern sebagai berikut:

Tabel 1. Ciri-ciri Masyarakat Tradisional, Transisi dan Modern

\begin{tabular}{lll}
\hline \multicolumn{1}{c}{ TRADISIONAL } & \multicolumn{1}{c}{ TRANSISI } & \multicolumn{1}{c}{ MODERN } \\
\hline - Berpindah-pindah & - Dualisme struktural yang & - Industri \\
- Teknologi primitif & memungkunkan kehadiran bersama & - Teknologi maju \\
- Sumber kekuasaan yang hidup & kereta lembu dan pesawat udara & - Sumber kekuasaan tidak \\
(animate) & - Kombinasi sumber kekuasaan yang & hidup \\
- Pembagian kerja yang sederhana & hidup serta perubahan budaya di & - Pembagian kerja berdasarkan \\
- Swasembada unit-unit sosial & mana norma-norma modernitas & fungsi independensi unit-unit \\
- Produksi primer & berangsur-angsur muncul di dalam & sosial \\
- Tradisi suci & kerangka nilai-nilai tradisional & - Produksi sekunder \\
- Organisasi komunal & - Industrialisasi & - Sekularisme \\
- Solidaritas mekanistik & - Urbanisasi & - Birokrasi impersonal \\
- Sistem status berdasarkan & - Mobilitas politik & - Solidaritas organik \\
keturunan & - Rekayasa sosial & - Mengutamakan prestasi \\
- Semangat kerakyatan (folk spirit) & & - Urbanisme \\
\hline
\end{tabular}

Sumber: Abraham, 1991. Hal. 12-13 
Ciri-ciri dari tiga bentuk masyarakat di atas berpijak dari sudut pandang pemikiran Barat. Konsep ini mungkin juga tidak seluruhnya bisa untuk menilai tipe masyarakat modern secara universal. Namun demikian, konsep ini dapat menjadi pertimbangan untuk menilai masyarakat di dunia saat ini.

\section{Dampak Perkembangan Teknologi dan Modernisasi}

\section{Dampak Perkembangan Teknologi dan Modernisasi}

Perkembangan teknologi dan modernisasi dapat mengakibatkan terbentuknya pola hidup baru dalam masyarakat. Terutama pada masyarakat di negara-negara yang sedang berkembang, seperti Indonesia. Pada negaranegara yang sedang berkembang, dengan adanya modernisasi mengakibatkan terjadinya transisi dalam kehidupan masyarakat dari bentuk tradisional menuju bentuk modern. Hal ini karena dilaksanakan industrialisasi, sekularisasi, diferensiasi struktural, spesialisasi fungsional, orientasi rasional; mengakibatkan perkembangan atau evolusi dari bentuk masyarakat tradisional yang sederhana, homogen dan folk menuju masyarakat perkotaan yang rumit dan heterogen (Abraham, 1991, pp.1213).

Masyarakat modern dapat berkembang secara dinamis melalui tiga aspek. Ketiga aspek tersebut menurut Gidden adalah sebagai berikut: (1) pemisahan waktu dan ruang atau distanciation; (2) keterlepasan atau disembedding; dan (3) refleksivitas atau reflexivity.

Karakter keterpisahan kehidupan modern menimbulkan sejumlah masalah tersendiri. Misalnya risiko yang berskala global seperti terjadinya perang nuklir, perubahan dalam pembagian kerja di seluruh dunia, pasar modal global, agama makin kurang penting. Hal ini memberikan modernitas perasaan seperti panser raksasa lepas kendali dan membuat kita tidak aman.

Di samping itu, Gidden juga mengungkapkan bahwa dunia modern juga menimbulkan "keterasingan pengalaman" (sequestration of experience) atau proses yang berkaitan dengan penyembunyian yang memisahkan rutinitas kehidupan sehari-hari dari fenomena-fenomena sebagai berikut: kegilaan, kriminalitas, penyakit, kematian, dan seksualitas. Keterasingan ini membawa kita kepada keamanan ontologis yang makin besar, tetapi dengan resiko "mengesampingkan kehidupan sosial dari masalah eksistensial fundamental yang menimbulkan dilema moral utama bagi umat manusia" (Ritzer, 2005, pp.555-569).

Berdasarkan pendapat psikologi, seperti Erich Formm mengungkapkan bahwa keterasingan muncul karena pengaruh kapitalisme. Keterasingan pada masyarakat modern itu hampir-hampir total. Manusia modern telah membangunkan dunianya sendiri sebagai sebuah mesin yang menakjubkan, dan kemudian mesin itu menguasainya. Dengan demikian manusia "tidak lagi merasakan dirinya sebagai pembawa aktif dari kekuatan dan kekayaannya, tetapi sebagai "benda" yang dimiskinkan, tergantung kepada kekuatan di luar dirinya, kepada siapa yang telah memproyeksikan substansi hayat dirinya." Demikianlah dalam dunia industri, pekerja telah kehilangan dirinya menjadi atom ekonomi dan bekerja sesuai dengan perintah dari manajemen yang atomik. Begitu juga manajer industri, ia juga kehilangan dirinya sendiri, karena seperti juga pekerja, semuanya menghadapi raksasa yang impersonal (Kuntowijoyo, 2006, p.110).

Perkembangan teknologi informasi, seperti teknologi digitalisasi berdampak pada terciptanya kebebasan individual. Bentukbentuk individualisasi antara lain kepemilikan nomor telepon seumur hidup, individualisasi dalam menonton televisi, belanja di rumah, pebankan di rumah, pesanan tempat duduk pesawat terbang dan kamar hotel, berita, sport, video game dengan dua pemain dari lokasi-lokasi yang berbeda, film dan MTV menurut permintaan, dan juga perpustakaan dan ensiklopedi, semua akan tersedia yang sama dengan alat remote control yang sekarang digunakan oleh konsumen untuk memilih saluran (Naisbitt, 1994, pp.95-97).

Kondisi kehidupan modern ternyata rentan terhadap munculnya perilaku-perilaku yang menyimpang akibat sistem informasi yang terbuka, kebebasan individu, gaya hidup yang hedonik, dan sebagainya. Misalnya kasus yang sedang marak di negeri kita sekarang ini, seperti kasus penyalahgunaan NAPZA yang semakin merajalela (Kompas, 29 Januari 2013); kasus korupsi baik di tingkat pemerintahan pusat maupun di daerah; kasus pembunuhan, kasus perkosaan, dan 
sebagainya. Hal tersebut tidak terlepas dari kondisi masyarakat yang belum bisa memaknai modernisasi itu sendiri. Kehidupan modern yang digambarkan oleh Gidden sebagai panser raksasa (Juggernaut) yang bila tidak terkendali maka akan mengancam kehidupan masyarakat modernitas itu sendiri.

\section{Perubahan-perubahan Akibat Modernisasi dalam Masyarakat}

Karakteristik kehidupan masyarakat modern memiliki perbedaan dengan karakteristik kehidupan masyarakat tradisional. Kondisi masyarakat yang berubah dari kehidupan tradisional menuju ke kehidupan modern, menampakkan gejala-gejala yang baru dalam masyarakat. Perubahan-perubahan yang terjadi baik yang direncanakan maupun tidak direncanakan berdampak langsung maupun tidak langsung pada perubahan pola hidup dan perilaku masyarakat. Beberapa perubahan penting yang terjadi akibat dari modernisasi menurut M. Francis Abraham antara lain perubahan sistematis, perubahan fungsional dan perubahan sikap dalam masyarakat tradisional (Abraham, 1991, pp.17-25). Perubahan-perubahan itu menurut Abraham dapat dijelaskan sebagai berikut:

\section{1) Perubahan Sistematis}

Perubahan sistemis berpengaruh pada perubahan perilaku masyarakat modern, terutama perubahan dalam keluarga. Dalam masyarakat modern terjadinya pemisahan pekerjaan dan rumah tangga mengarah kepada individualisasi dan isolasi keluarga inti sebagai unit produksi. Terjadinya perubahan dari sistem ekonomi pertanian dan kerajinan tangan menjadi sistem industri modern berpengaruh terhadap jumlah anggota keluarga, hubungan emosional dan sosialisasi anak. Dalam keluarga terjadi pergantian dari keluarga besar menjadi keluarga inti, keluarga lokal baru, dan keruntuhan sistem magang. Keluarga juga kehilangan banyak fungsi biasanya, misalnya fungsi pendidikan, agama dan rekreasi. Hubungan kerja yang rasional berdasarkan gaji (upah) menjadikan hubungan-hubungan dalam keluarga menurun dan renggang. Sistem stratifikasi sosial semakin terbuka dan fleksibel, dan mobilitas sosial yang terbuka berdasarkan prestasi yang diraih (Abraham, 1991, pp.1819).

\section{2) Perubahan Fungsional}

Modernisasi juga berpengaruh terhadap perubahan fungsional dalam menciptakan profesi baru dan mengakibatkan perubahan mendasar dalam pola lapangan kerja. Perubahan fungsional pada masyarakat modern akibat perkembangan teknologi yang pesat berdampak pada perubahan fungsifungsi yang dijalankan oleh keluarga, marga, suku, kasta, agama atau masyarakat desa. Peranan dominan pemerintahan terpusat dan sifat hubungan sosial yang formal dan impersonal yang dipelihara oleh masyarakat massa yang melakukan urbanisasi, menghapuskan mekanisme kontrol tradisional yang didasarkan pada tekanan informal oleh keluarga, kelompok lokal (kedaerahan) atau pemimpin kelompok. Perubahan fungsional yang lain mencakup otomatisasi dan akibat kesalahan penempatan tenaga kerja, profesionalisasi berbagai peranan secara meluas, termasuk peranan perkawinan dan orang tua serta komersialisasi kegiatan-kegiatan waktu senggang (Abraham, 1991, pp.19-20). Perubahan-perubahan ini dapat mengakibatkan pada munculnya tindak kejahatan seperti korupsi, mark $u p$, atau salah urus dalam suatu urusan.

Perubahan fungsional penting lainnya ialah apa yang disebut "emansipasi wanita". Dalam hal ini terjadi perubahan pola sosialisasi dan orientasi nilai membantu menyapih wanita jauh dari belenggu tradisi, dan sebagai instrumen untuk melakukan mobilisasi politik baru mendorong wanita masuk ke dalam pekerjaan yang bergaji dan bergengsi (Abraham, 1991:19-21). Tentu saja perubahan-perubahan fungsional ini tidaklah semua berdampak positif, tetapi juga berdampak pada perubahan perilaku pada masyarakat yang sering disebut sebagai perilaku menyimpang, seperti wanita bekerja sebagai sopir, tukang parkir, kuli atau pekerjaan-pekerjaan yang dulunya dianggap tidak layak bagi wanita.

\section{3) Perubahan Sikap}

Modernisasi tidak hanya meliputi peningkatan diferensiasi sistem sosial, tetapi juga transformasi progresif dalam sikap pelaku sosial. Sikap modern terlihat seperti yakin akan keutamaan ilmu dan teknologi, percaya terhadap tujuan inovasi dan perubahan, sangat berorientasi pada kemajuan dan prestasi, dan yakin akan cara sekuler mengerjakan segala sesuatu, rasionalitas, mene- 
kankan pada nilai-nilai material, efisiensi kepemimpinan dan penggunaan waktu, produktivitas, dorongan rasional untuk memaksimalkan keuntungan, keterbukaan terhadap pengalaman baru, keinginan menerima resiko, aspirasi pendidikan yang tinggi, empati yang lebih besar dan individualisme yang besar. Sikap-sikap itu dipandang sebagian dari sindrom sifat kepribadian modern. Sebaliknya, sikap-sikap tradisional didasarkan pada pengalaman yang bertumpuk pada tradisi (Abraham, 1991, p.21).

Selanjutnya Abraham menjelaskan bahwa industrialisasi, urbanisasi dan birokratisasi mengakibatkan masyarakat kehilangan pegangan masa lalu yang berdasarkan sistem kepribadian individu dan merusak kesetiaan pada desa leluhur dan pemilikan tanah serta mendorong transaksi pasar semua barangbarang kapital dan jasa. Hal ini juga mengakibatkan mengembangkan revolusi sosial harapan yang meningkat, radikalisme, aktivisme, dan berbagai gerakan ideologi (Abraham, 1991, p.21).

\section{Perilaku Menyimpang pada Masyarakat Modern}

\section{1) Pengertian Perilaku Menyimpang}

Perilaku menyimpang merupakan bentuk penyimpangan sosial dalam masyarakat. Mengenai pengertian perilaku menyimpang pada para ahli terdapat banyak perbedaan. Rock seperti yang dikutip oleh Supardan, menyimpulkan dari berbagai pendapat para sosiolog dan kriminolog, bahwa penyimpangan sosial sebagai perilaku yang terlarang, perlu dibatasi, disensor, diancam hukuman, atau label lain yang dianggap buruk sehingga istilah tersebut sering dipadankan dengan pelanggaran aturan (Supardan, 2011, p.144).

Pendapat lain tentang penyimpangan sosial disampaikan oleh beberapa sosiolog antara lain: pertama, pendapat dari Matza dalam Bukunya Becoming Deviant (1967). Matza mengaitkan penyimpangan dengan evaluasi majemuk, pergeseran standar penilaian, dan ambivalensi moral. Kedua, pendapat dari Garfinkel dalam bukunya Studies in Etnometodology (1967), dan Goffman dalam Stigma (1963), bahwa penyimpangan sebagai cerminan upaya penyesuaian diri sebagian anggota masyarakat dalam mengatasi persoalannya, yang tidak jarang berbenturan dengan standar-standar umum. Ketiga, Scott dan
Douglas dalam tulisannya Theoretical Perspectives on Devience (1972), mengemukakan bahwa yang terpenting ciri penyimpangan terletak pada penilaian pihak lain yang menganggapnya aneh (Supardan, 2011, p.145).

2) Bentuk-bentuk Perilaku Menyimpang dalam Masyarakat Modern

Dalam kehidupan masyarakat transisi seperti di Indonesia, sikap modern belum menjiwai sebagian besar masyarakat. Pada umumnya masyarakat belum menjunjung tinggi sikap kedisiplinan, profesionalitas, produktivitas, sportivitas, dan tanggung jawab, serta menjaga kepercayaan. Akan tetapi, sikap individualisme, konsumerisme dan hedonisme lebih dominan dalam kehidupan masyarakat. Masyarakat lebih mudah menerima dan mengkonsumsi produk asing serta berusaha untuk memuaskan semua kebutuhan hidupnya dengan segala cara dan kurang bermoral. Tindakan-tindakan itu melahirkan bentuk korupsi, kolusi dan nepotisme. Kasus-kasus yang muncul seputar korupsi di sekitar politisi yang marak pada dewasa ini merupakan fenomena yang menunjukkan bentuk perilaku menyimpang masyarakat modern (kompas.com/2013/3/7).

Dari berbagai data yang diperoleh dari berbagai sumber mengenai bentuk-bentuk perilaku yang menyimpang dapat dikelompokkan sebagai berikut:

a) Seks bebas atau frer sex

Seks bebas atau free sex yang dilakukan oleh remaja pada akhir-akhir ini telah mengkhawatirkan semua pihak. Sarlito W. Sarwono mencatat banyak kasus free sex yang dilakukan oleh para remaja dari berbagai sumber tulisan (Sarwono, 2011, pp.171-174). Berdasarkan data yang diperoleh dari Kementerian bahwa pada tahun 2009 bahwa hasil penelitian di empat kota yakni Jakarta Pusat, Medan, Bandung, dan Surabaya yang menunjukkan sebanyak 35,9 persen remaja punya teman yang sudah pernah melakukan hubungan seksual sebelum menikah. Bahkan, 6,9 persen responden telah melakukan hubungan seksual sebelum menikah (Vemale.com, 03 Desember 2012).

Berdasarkan penelitian yang dilakukan Australian National University dan Universitas Indonesia (UI) terhadap remaja di Indonesia kondisinya sangat memprihatinkan. 
'Ini sangat memprihatinkan, karena dari 3.600 responden penelitian itu, sebanyak 20,9 persen remaja itu telah hamil di luar nikah, 'Pernyataan tersebut disampaikan oleh Sudibyo Alimoeso Deputi Keluarga Sejahtera dan Pemberdayaan Keluarga (KSPK) BKKBN (riaupos.col, 5 November 2012).

Munculnya perilaku free sex dan kenakalan pada anak-anak remaja karena beberapa faktor, antara lain: (a) akibat kontrol sosial yang lemah dari keluarga, (b) pengaruh teman pergaulan dan (c) perkembangan teknologi modern, khususnya teknologi komunikasi cenderung menyajikan gambar porno dan video porno.

b) Perselingkuhan

Perilaku ini dilakukan oleh laki-laki dan perempuan yang telah menikah. Dewasa ini kasus perselingkuhan menjadi merebak, bak seperti tren. Merebaknya kasus perselingkuhan salah satunya disebabkan oleh renggangnya hubungan suami istri karena berubahnya fungsi keluarga, seperti hubungan kerja di kantor yang melebihi dari hubungun dengan suami/istri. Berdasarkan data tahun 2012 diketahui bahwa di Indonesia angka perselingkuhan mencapai 10.029 kasus. Jawa Timur prihatin dengan tingginya angka perselingkuhan, karena menempati peringkat pertama di Indonesia dengan 7.172 kasus. Peringkat kedua ditempati Jawa Barat dengan 3.650 kasus dan ketiga Jawa Tengah dengan 2.503 kasus (suarakawan.com/28/06/2012/)

c) Tawuran pelajar.

Perilaku menyimpang yang juga mengkhawatirkan semua pihak adalah tawuran pelajar. Kondisi ini dipengaruhi oleh banyak faktor, antara lain kurangnya perhatian orang tua kepada anak karena orang tua sibuk bekerja, dan pergaulan remaja yang kurang sehat. Keterangan yang diperoleh dari Komisi Nasional Perlindungan Anak (Komnas PA) diketahui data catatan tawuran pelajar sepanjang tahun 2012 hingga 25 Desember 2012, telah terjadi sebanyak 147 tawuran. Peristiwa itu menyebabkan 82 pelajar tewas. Angka ini meningkat dibanding tahun 2011 yang hanya terjadi 128 kasus, dan menewaskan 30 pelajar (beritabatavia.com/2012/12/28/).

\section{d) Bunuh Diri}

Berdasarkan data bahwa kasus bunuh diri di Indonesia belakangan ini dinilai cukup memprihatinkan karena angkanya cenderung meningkat sehingga perlu mendapat perhatian serius pemerintah, kata seorang sumber. WHO atau Organisasi Kesehatan Dunia pada 2010 melaporkan angka bunuh diri di Indone-sia mencapai 1,6 hingga 1,8 per 100.000 jiwa. Perkiraan WHO memperkirakan pada 2020 angka bunuh diri secara global menjadi 2,4 per 100.000 jiwa dibandingkan 1,8 per 100.000 jiwa pada 1998 (republika.co.id/12/06/01).

e) Tindakan Kriminal

Di Indonesia bentuk tindakan kriminal (kejahatan) meningkat dengan pesat pada tahun-tahun terakhir. Berdasarkan data yang dikeluarkan Polda Metro Jaya seperti yang ditayangkan oleh TVOne pada 1-11-2011, dinyatakan bahwa di Jakarta setiap 9-10 menit terjadi 1 tindakan kriminal baik itu kriminal berat maupun kriminal kategori ringan yang antara lain: pembunuhan, pemerkosaan, pencurian, penipuan, narkotika dan lain-lain. Dalam sehari rata-rata terjadi 120-144 tindakan kriminal dan setahunnya 43.800-52.560 kasus tindakan kriminal. Data ini disinyalir lebih kecil dari fakta yang ada di masyarakat. Seperti fenomena gunung es, yang dilaporkan lebih kecil dari kejadian yang ada. Jika seandainya tindakan kriminal di setiap provinsi lainnya terjadi separuh dari jumlah di ibukota tersebut dan setiap kejadian dilakukan oleh 1 orang maka setiap tahunnya sekitar 6-7\% penduduk Indonesia melakukan tindakan kriminal (hankam.kompasiana.com/2012/01/ 04).

Tindakan kriminal yang muncul di masyarakat dapat dikelompokkan menjadi beberapa bentuk, antara lain:

\section{(1) Pencurian}

Tindakan pencurian yang marak pada tahun-tahun terakhir ini menurut laporan kepolisian dapat dikategorikan dalam tiga bentuk, yaitu pencurian dengan pemberatan (curat), pencurian kendaraan bermotor (curanmor), dan pencurian dengan kekerasan (curas). Menurut data bahwa selama tahun 2012 bahwa di wilayah polres Bantul saja ditemukan kasus curat sebanyak 140 buah, kasus curanmor sebanyak 72 buah (sebanyak 21 dapat diungkap), dan kasus curas sebanyak 56 buah yang diantaranya 21 juga dapat diungkap (tribunnews.com/ 2012/12/23/). 


\section{(2) Pembunuhan}

Pembunuhan juga merupakan tindakan kriminal yang seringkali muncul pada masyarakat modern. Menurut data bahwa di Jakarta saja, khusus untuk pembunuhan rata-rata pertahun terjadi 86 kasus. Ditahun 2011, hingga periode Oktober saja, sudah terjadi 85 kasus pembunuhan. Kasus ini kemungkinan akan terus meningkat hingga akhir tahun (hankam.kompasiana.com/ 2012/01/04/).

\section{(3) Pemerkosaan}

Tindakan pemerkosaan dapat dikelompokkan dalam perkosaan terhadap anakanak dan perkosaan terhadap orang dewasa. Menurut data yang dapat diperoleh bahwa kasus perkosaan anak di Kabupaten Kendal, Jawa Tengah, pada tahun 2011 bertambah hingga 400 persen dibanding tahun sebelumnya. Kabupaten Kendal menyebutkan, kasus pemerkosaan yang menimpa pada anak ada 41 kasus. Sementara pada tahun 2010 ada sem-bilan kasus. Usia korban rata-rata sekitar 13-18 tahun. "Pada bulan Januari 2012 hingga sekarang, sudah ada delapan kasus yang menimpa pada anak. Lima kasus pencabulan dan tiga kasus pemerkosaan," kata Kepala Bidang BPPKB Kendal, Yulianto (hizbuttahrir. or.id /2012/02/29/).

Secara nasional, angka pemerkosaan sudah tinggi sekali. Data pada tahun 2011, kasus kekerasan terhadap perempuan di Indonesia didominasi oleh angka perkosaan, yakni 400.939 dan angka terbanyak (70.115 kasus) perkosaan ternyata dilakukan dalam rumah tangga. Pelaku perkosaan dilakukan oleh suami, orangtua sendiri, bahkan saudara dan keluarga terdekat. Sementara perkosaan di tempat umum (publik) sebanyak 22.285 kasus, diantaranya yang akhir-akhir ini banyak dibicarakan dan di media massa tentang perkosaan di angkot. Selain itu, negara telah melakukan kekerasan yang sama karena telah membiarkan 1.561 kasus perkosaan yang tidak terselesaikan (polhukam.kompasiana. com/hukum/2012/02/05/)

\section{(4) Penyalahgunaan Narkoba}

Narkoba (Narkotika dan Obat-obatan Terlarang) telah merebak di Indonesia, terutama di kota-kota besar. Berdasarkan keterangan dari Kepolisian Metro Jaya (Ja- karta) bahwa telah berhasil diungkap penyalahgunaan narkoba senilai Rp 2,12 triliun disepanjang tahun 2012 atau menyelamatkan sekitar 21 juta jiwa warga yang menjadi sasaran peredaran narkoba (detikNews, 12 Juli 2012). Para konsumen Narkotika kebanyakan generasi muda yang masuk kategori produktif.

\section{(5) Terorisme}

Terorisme merupakan salah satu tindakan kejahatan yang juga cukup memprihatinkan di Indonesia. Badan Nasional Penanggulangan Terorisme menyebutkan ancaman terorisme masih ada di Indonesia, dengan banyaknya penangkapan belasan orang yang diduga pemilik bahan peledak dan disebut masih terkait dengan jaringan lama. Menurut BNPT terkait dengan sejumlah peristiwa pelatihan di Poso, ledakan bom di Beji, Depok Jawa Barat September lalu, dan kepemilikan bahan peledak di Solo. Kepala BNPT Ansyaad Mbai menyebutkan belasan orang yang ditangkap itu masih terkait dengan jaringan lama, salah satunya Noordin M Top dan memiliki kemampuan menggalang dana milyaran rupiah dan memilki anggota berpendidikan tinggi, merupakan bukti masih adanya ancaman terorisme di Indonesia (bbc.co.uk/ indonesia/laporankhusus/2012/10/121010).

Kasus terorisme yang terjadi pada tahun 2011 ini terkait seperti ledakan bom buku di Komunitas Utan Kayu Raya nomor $68 \mathrm{H}$, Jakarta Timur pada tanggal 15 Maret 2011 lalu. Selain itu, pengungkapan kasus bahan peledak di depan gereja Christ Cathedral, Jalan Telaga Gading Serpong, Kabupaten Tangerang, pada tanggal 21 April 2011 lalu. Polisi menangkap 21 orang tersangka dalam kasus ini, termasuk otak pelaku berinisial $\mathrm{P}$ (sutradara film). Dari hasil penyidikan, $P$ ternyata juga pela$\mathrm{ku}$ pengiriman paket bom buku di Utan Kayu (kompas.com/30 Desember 2011).

\section{(6) Korupsi}

Korupsi merupakan penyakit dalam masyarakat di seluruh dunia, baik negara maju maupun negara berkembang. Anehnya di negara-negara yang sedang berkembang kasus korupsi lebih banyak dari negara-negara yang maju.

Di Indonesia, kasus korupsi banyak dilakukan oleh para pejabat dan politisi di 
pusat maupun di daerah. Permadi menyebutkan bahwa korupsi dilakukan mulai dari yang recehan, seperti pemilihan fasilitas kelas penerbangan. Semestinya kelas bisnis, diubah menjadi ekonomi supaya anggaran bisa dikantongi. Modus korupsi juga dilakukan sewaktu masa reses DPR. Anggota Dewan semestinya bertemu konstituen. Nyatanya, hanya Rp 2,5 juta saja yang dibagi-bagikan ke konstituen di daerah. Itu pun dibagikan oleh sopir. "Sisanya, sekali lagi, dikantongi," ujar Permadi. Tak hanya di DPR, di kementerian pun tidak luput dari praktik korupsi. Kasus dugaan korupsi daging impor sapi yang melibatkan tokoh partai politik dan sejumlah pejabat di Kementerian Pertanian dan juga korupsi di Kementerian Agama (kompas.com/2013/ 3/7/).

Menurut pendapat Kriminolog Erlangga Masdiono bahwa tingginya angka kriminal di Indonesia disebabkan oleh berbagai macam faktor, antara lain kemiskinan, disfungsi norma dan hukum, ketidakharmonisan unsur terkait serta karakter bangsa yang sudah bergeser. Hal ini diperparah dengan sistem pendidikan yang tidak lagi mengajarkan nilainilai etika termasuk pendidikan agama yang hanya menekankan pada aspek kognitifnya (hankam.kompasiana.com/04 Januari 2012)

\section{SIMPULAN}

Dari pembahasan di atas penulis menyimpulkan bahwa perkembangan teknologi merupakan sebuah keniscayaan yang tidak bisa dihindari pada masyarakat modern. Perkembangan teknologi pada era informasi ini semakin cepat dan pesat ditandai dengan perkembangan teknologi telekomunikasi yang mengakibatkan terbentuknya ekonomi global.

Perkembangan teknologi tidak terlepas dari proses modernisasi yang melanda di seluruh dunia, baik di negara-negara maju maupun di negara-negara yang sedang berkembang. Secara umum proses modernisasi dapat dikelompokkan dalam dua tipe, yaitu modernisasi ekonomi dan sosial. Kedua tipe modernisasi tersebut yang membawa perubahan masyarakat dari bentuk tradisional yang sederhana menjadi masyarakat kekotaan yang kompleks dan rumit.

Meskipun di satu sisi perkembangan teknologi dan modernisasi memberikan kesenangan dan kemudahan bagi masyarakat, seperti kelancaran dalam berkomunikasi. Namun, di sisi lain perkembangan teknologi dan modernisasi berdampak negatif dalam kehidupan masyarakat modern. Perubahanperubahan yang terjadi akibat proses modernisasi membuat manusia merasa dalam keterasingan. Modernisasi seakan menjadi panser raksasa yang menakutkan dan sewaktuwaktu mengancam manusia itu sendiri bila tidak dapat mengendalikan perubahan itu.

Hal ini bisa kita lihat dari munculnya perilaku-perilaku menyimpang dari masyarakat modern. Pada prinsipnya, munculnya perilaku-perilaku menyimpang seperti munculnya kasus seks bebas, perselingkuhan, korupsi, penyalahguanaan NAPZA, pembunuhan, pemerkosaan dan jenis kriminalitas lainnya. Kasus-kasus tersebut bila tidak teratasi dapat mengancam eksistensi kehidupan modern yang sedang kita bangun bersama.

Terjadinya perilaku yang menyimpang dan tingginya angka kejahatan di Indonesia disebabkan oleh beberapa faktor antara lain kemiskinan, disfungsi norma dan hukum, ketidakharmonisan unsur terkait serta karakter bangsa yang sudah bergeser. Di samping itu juga akibat sistem pendidikan yang tidak lagi mengajarkan nilai-nilai etika termasuk pendidikan agama yang hanya menekankan pada aspek kognitifnya

\section{DAFTAR PUSTAKA}

Abraham, M. Francis. (1991). Modernisasi di Dunia Ketiga Suatu Teori Umum Pembangunan. (Terjemahan M. Rusli Karim). Penerbit: University Press of America, (Buku asli diterbitkan tahun 1980).

Bbc.co.uk. (12 Oktober 2012). Tersangka kasus terorisme masih terkait jaringan lama.

Beritabatavia.com. (28 Desember 2012). 2012 82 Pelajar Tewas Karena Tawuran.

Dwiningrum, Siti Irene Astuti. (2012). Ilmu Sosial dan Budaya Dasar. Yogyakarta: UNY Press. Cetakan pertama.

DetikNews. (12 Juli 2012). Komnas PA: 147 Tawuran Pelajar Pecah Selama 2012, 82 Anak Tewas. 
Hankam.kompasiana.com. (04 Januari 2012). Indonesia dalam Bingkai Kriminalitas.

Hizbut-tahrir.or.id. (29 Februari 2012). Kasus Perkosaan Anak Melonjak 400 Persen.

Kasali, Rhenald. (2005). Change! Tak Peduli Berapa Jauh Jalan Salah yang Anda Jalani, Putar Arah Sekarang Juga. Jakarta: Penerbit PT. Gramedia Pustaka Utama. Cetakan keenam.

Kuntowijoyo. (2006). Budaya dan Masyarakat. Yogyakarta: Tiara Wacana. Edisi paripurna cetakan pertama.

Kompas.com. (30 Desember 2011). Catatan Kriminalitas di Jabodetabek Selama 2011.

Kompas.com.(29 Januari 2013). Narkoba Kian Merajalela, Terpidana Mati Kendalikan Pasar.

Kompas.com. (7 Maret 2013). Korupsi di Sekitar Politisi.

Naisbitt, John. (1994). Global Paradox, Semakin Besar Ekonomi Dunia, Semakin Kuat Perusahaan Kecil. (Terjemahan Drs. Budijanto). Penerbit: William Morrow and Company, (Buku asli diterbitkan tahun 1994).

Polhukam.kompasiana.com. (05 Februari 2012). Kriminalitas Meningkat, Hukum
Indonesia Gagal Melindungi Rakyatnya!.

Republika.co.id. (01 Juni 2012). Memprihatinkan, Kasus Bunuh Diri di Indonesia

Rioupos.co. (5 November 2012).

Ritzer, George \& Douglas J. Goodman. (2004). Teori Sosial Modern. (terjemahan Alimandan). Penerbit: McGrew Hill. (Buku asli diterbitkan tahun 2003).

Sarlito W. Sarwono. (2011). Psikologi Remaja. Jakarta: Rajawali Press. Cetakan ke14.

Stark, Rodney. (1992). Sociology, California: Wadsworth Publishing Company. $4^{\text {th }} \mathrm{ed}$

Suarakawan.com. (28 Juni 2012). Wouw, Jatim Rangking Pertama Perselingkuhan di Indonesia.

Supardan, Dadang. (2011). Pengantar Ilmu Sosial Sebuah Kajian Pendekatan Struktural. Jakarta: Penerbit Bumi Aksara. Cetakan ketiga.

Tribunnews.com. (23 Desember 2012). Curat Mendominasi Catatan Kriminal Selama 2012.

Vemale.com. (03 Desember 2012). 35,9 Persen Remaja Indonesia Lakukan Seks Bebas. 